
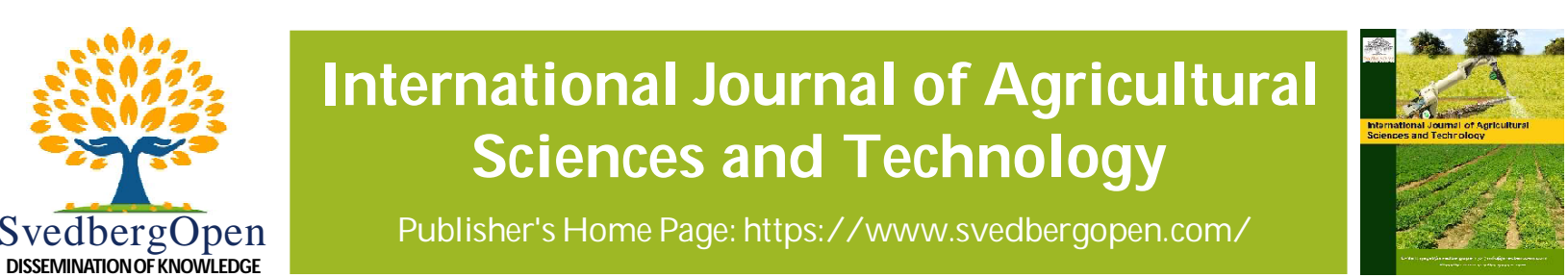

\title{
Improved Salinity Tolerance by Potassium Humate Fertilizer in Common Bean (Phaseolus vulgaris L., Cv. "Bronco") Plants
}

\author{
Mohamed A. Seif El-Yazal ${ }^{1 *}$, Ahmed A. El-Shewy ${ }^{2}$, Kariman E.S. Abdelaal ${ }^{3}$ and Mostafa M. Rady ${ }^{4}$ \\ ${ }^{1}$ Botany Department, Faculty of Agriculture, Fayoum University, Fayoum 63514, Egypt. E-mail: mas04@fayoum.edu.eg \\ ${ }^{2}$ Botany Department, Faculty of Agriculture, Fayoum University, Fayoum 63514, Egypt. E-.mail: aas01@fayoum.edu.eg \\ ${ }^{3}$ Botany Department, Faculty of Agriculture, Fayoum University, Fayoum 63514, Egypt. E-mail: kes05@fayoum.edu.eg \\ ${ }^{4}$ Botany Department, Faculty of Agriculture, Fayoum University, Fayoum 63514, Fayoum 63514, Egypt. E-mail: mmr02@fayoum.edu.eg
}

\section{Article Info}

Volume 1, Issue 4, November 2021

Received : 19 July 2021

Accepted : 25 October 2021

Published : 05 November 2021

doi: 10.51483/IJAGST.1.4.2021.47-57

\begin{abstract}
The objective of this study is to assess the ameliorative impact of potassium humate $(\mathrm{KH}$; 0,100 , and $200 \mathrm{~kg}$ per feddan) as soil amendments on the growth traits, green and dry yields characteristics, leaf photosynthetic pigments, chlorophyll fluorescence, and leaf contents of nutrients of common bean (Phaseolus vulgaris L., cv. "Bronco") plants grown under saline soil conditions. To perform the study aim, two field trials were conducted at the Experimental Farm of Faculty of Agriculture, Fayoum University during the 2016 and 2017 summer seasons. The obtained results showed that, $\mathrm{Na}^{+}$content was significantly declined, while the all other tested parameters such as growth characteristics (i.e., shoot length, number of leaves per plant, area of leaves per plant, and shoot fresh and dry weights), yield characteristics of green pods and dry seeds (i.e., average pod weight, number of pods per plant, pods weight per plant, dry seed weight per plant and 100-seed weight), leaf photosynthetic pigments (i.e., total chlorophylls, total carotenoids) contents and leaf chlorophyll fluorescence (i.e., $\mathrm{Fv} / \mathrm{Fm}$ and PI), leaf contents of $\mathrm{N}, \mathrm{P}, \mathrm{K}^{+}$, and $\mathrm{Ca}^{2+}$, and the ratios of $\mathrm{K}^{+} / \mathrm{Na}^{+}, \mathrm{Ca}^{2+} / \mathrm{Na}^{+}$and $\mathrm{K}^{+}+\mathrm{Ca}^{2+} / \mathrm{Na}^{+}$were significantly increased by the all $\mathrm{KH}$ treatments compared to the controls (without $\mathrm{KH}$ ). The two $\mathrm{KH}$ treatments conferred, approximately, the same results. Therefore, results of this study recommend using $\mathrm{KH}$ at $100 \mathrm{~kg}$ per feddan to optimize the common bean performance in saline soils.
\end{abstract}

Keywords: Phaseolus vulgaris, Salinity, Humic substances, Plant performance, Antioxidant defense systems, Photosynthesis, Water relations

(C) 2021 Mohamed A. Seif El-Yazal et al. This is an open access article under the CC BY license (https://creativecommons.org/licenses/by/4.0/), which permits unrestricted use, distribution, and reproduction in any medium, provided you give appropriate credit to the original author(s) and the source, provide a link to the Creative Commons license, and indicate if changes were made.

\section{Introduction}

Food legumes are considered as an important component in promoting sustainable agriculture and human dietary nutrition, worldwide. Legumes are a health-promoting source of protein, especially the common bean (Phaseolus vulgaris L.) that constitutes $50 \%$ of the total grain legumes consumed globally (Broughton et al., 2003). Legume cultivation is beneficial to non-legume crops through multiple agro-ecological services such as biological nitrogen fixation, improvement of soil fertility and N-rich green manure (Isaac et al., 2011). However, the economical, nutritional and ecological services provided by legumes are often compromised by sensitivity to environmental stresses whose increased frequency can

* Corresponding author: Mohamed A. Seif El-Yazal, Botany Department, Faculty of Agriculture, Fayoum University, Fayoum 63514, Egypt. E-mail: mas04@fayoum.edu.eg 
reduce major crop production by more than half (Wang et al., 2003). Phaseolus vulgaris (L.) is one of the most important Fabaceae vegetables produced for human nutrition, particularly in the Middle Eastern, including Egypt. It is classified as a salt-sensitive plant (Maas and Hoffman, 1977).

Soil salinity is one of the major problems of agriculture, particularly in arid and semiarid regions, limiting plant growth and productivity (Munns and Tester, 2008; Bargaz et al., 2016). Salt stress adversely affects plant morphology and physiology through osmotic and ionic stresses, and changes biochemical responses in plants (Khan et al., 2013). It causes an overproduction of Reactive Oxygen Species (ROS) such as superoxide $\left(\mathrm{O}_{2}^{*}\right)$, hydrogen peroxide $\left(\mathrm{H}_{2} \mathrm{O}_{2}\right)$ and hydroxyl $\left(\mathrm{OH}^{*}\right)$ radicals. Chloroplasts are the major organelles that produce the ROS during photosynthesis (Asada, 1999; Hemida et al., 2017). The ROS cause damages for lipids, proteins and DNA (Yasar et al., 2006). They also cause chlorophyll degradation and membrane lipid peroxidation (Yildirim et al., 2008). Removal of the toxic ROS rapidly is important in any defense mechanism. This elimination occurs through antioxidant defense systems (Mishra et al., 2009). There are several reports underlining the intimate relationship between the activity of antioxidant systems and increased tolerance to environmental stresses (Bargaz et al., 2016; Hemida et al., 2017). Differences in the accumulation patterns of $\mathrm{Na}^{+}$and $\mathrm{K}^{+}$are found under salinity stress. Salt tolerant species maintain a high $\mathrm{K}^{+}$content accompanied by a higher $\mathrm{K}^{+} / \mathrm{Na}^{+}$ratio (Bargaz et al., 2016).

Application of humic substances in agriculture as a fertilizer/a soil conditioner was tried and their positive impacts on saline soil structure and plant growth were reported (Osman and Rady, 2012; Semida et al., 2015; Rady et al., 2016; Hemida et al., 2017). In these reports, application of humic acid (HA) or potassium humate (KH) in appropriate levels improved plant growth and yield, and nutrient status of plants under normal or soil salinity stress conditions.

Accordingly, the present work was designed with the objective to evaluate the potential ameliorative effects of KH as a soil amendment on the changes in the growth and green and dry yields characteristics, leaf photosynthetic pigments, chlorophyll fluorescence, and leaf contents of nutrients of Phaseolus vulgaris L. plants exposed to soil salinity stress $\left(E C_{e}=7.80-7.86 \mathrm{dS} \mathrm{m}^{-1}\right)$.

\section{Materials and Methods}

\subsection{Experimental Site}

Two field experiments were conducted during the summer seasons of 2016 and 2017 at the Experimental Farm of the Faculty of Agriculture, Fayoum University, Southeast Fayoum (29 $17^{\prime} \mathrm{N}$; 30 $33^{\circ}$ 'E), Egypt.

Soil analyses: Assessments of the main soil chemical and physical characteristics (Table 1) were performed according to the procedures of Page et al. (1982) and Klute (1986). Based on the determined $E C_{e}$ values in both seasons (7.86 and $7.80 \mathrm{dS} \mathrm{m}^{-1}$, respectively), the soil is classed as being saline according to Dahnke and Whitney (1988).

Table 1: Physical and Chemical Properties of the Experimental Soil During Soil Preparation for Sowing in Two Seasons

\begin{tabular}{|l|c|c|}
\hline Parameter & 2016 Season & \multicolumn{2}{|c|}{ 2017 Season } \\
\hline Clay & 41.0 & 40.5 \\
\hline Silt & 35.5 & 35.0 \\
\hline Sand & 23.5 & 24.5 \\
\hline Soil Texture & \multicolumn{2}{|c|}{ Clay Loam } \\
\hline pH & 7.79 & 7.76 \\
\hline EC $\left(\mathrm{dS} \mathrm{m}^{-1}\right)$ & 7.86 & 7.80 \\
\hline Organic Matter $(\%)$ & 0.81 & 0.84 \\
\hline CEC $\left(\mathrm{cmol}_{\mathrm{c}} \mathrm{kg}^{-1}\right)$ & 5.54 & 5.60 \\
\hline Field Capacity $(\%)$ & 32.6 & 32.8 \\
\hline Available Water $(\%)$ & 28.4 & 28.8 \\
\hline
\end{tabular}


Table 1 (Cont.)

\begin{tabular}{|l|c|c|}
\hline Parameter & 2016 Season & 2017 Season \\
\hline Available $\mathrm{N}\left(\mathrm{mg} \mathrm{kg}^{-1}\right.$ soil) & 111.7 & 122.8 \\
\hline Available $\mathrm{P}\left(\mathrm{mg} \mathrm{kg}^{-1}\right.$ soil) & 16.4 & 18.9 \\
\hline Available K (mg kg${ }^{-1}$ soil) & 142.8 & 46.3 \\
\hline Available Fe (mg kg${ }^{-1}$ soil) & 45.1 & 22.9 \\
\hline Available $\mathrm{Mn}\left(\mathrm{mg} \mathrm{kg}^{-1}\right.$ soil) & 22.4 & 11.6 \\
\hline Available $\mathrm{Zn}\left(\mathrm{mg} \mathrm{kg}^{-1}\right.$ soil) & 11.0 & \\
\hline Note: ${ }^{*} \mathrm{CEC}$; cation exchange capacity. & & \\
\hline
\end{tabular}

\section{Materials and Treatments}

Potassium humate $(\mathrm{KH})$ used was purchased (Alpha Chemika, Mumbai, India) and found to contain approximately $60 \%$ humic acid (HA) and $15 \%$ potassium oxide $\left(\mathrm{K}_{2} \mathrm{O}\right)$, besides traces of other elements. It was used at three levels (i.e., 0,100 or $200 \mathrm{~kg}$ per feddan). The selected levels of $\mathrm{KH}$ for the two main field experiments were based on a pot preliminary study (data not shown).

Healthy common bean (Phaseolus vulgaris L., cv. Bronco) seeds were obtained from The Horticulture Research Institute, Agricultural Research Centre, Giza, Egypt, and were sown on 27 February 2016, and on 26 February 2017. Seeds were selected for uniformity by choosing those of equal size and same color. They were washed with distilled water, sterilized in $1 \%(\mathrm{v} / \mathrm{v})$ sodium hypochlorite for approximately $2 \mathrm{~min}$, and washed thoroughly again with distilled water. The sterilized seeds were left to dry at room temperature $\left(22 \pm 2^{\circ} \mathrm{C}\right)$.

Commercial rhizobia inoculants were applied as peat slurry containing 107 Rhizobium g-1 ${ }^{-1}$ Uniform, air-dried seeds were field sown on two different adjacent locations; one for 2016 season and the other for 2017 season, in the same Farm. Each location was divided into nine experimental units allocated for three treatments (three replicates per each) including the control. The recommended seed rate of $35-40 \mathrm{~kg}$ per feddan for common beans was used. Each experimental unit was consisted of five rows, $3 \mathrm{~m}$ long and $0.7 \mathrm{~m}$ wide (each unit $=10.5 \mathrm{~m}^{2}$ ), within row spacing was approximately $7.5 \mathrm{~cm}$. Thinning of plants (two per hill) was performed prior to the first irrigation. During preparation and plant growth, the soil was supplemented in total with ammonium sulphate $[20.5 \%(\mathrm{w} / \mathrm{w}) \mathrm{N}]$, calcium superphosphate $\left[15.5 \%(\mathrm{w} / \mathrm{w}) \mathrm{P}_{2} \mathrm{O}_{5}\right]$ and potassium sulphate $\left[48 \%(\mathrm{w} / \mathrm{w}) \mathrm{K}_{2} \mathrm{O}\right]$. The supplemented amounts were at a corresponding of 200, 200 and $100 \mathrm{~kg}$ per feddan, respectively as recommended for reclaimed saline soils.

The experimental design was complete randomized blocks with 3 levels of each of $\mathrm{KH}$ and $\mathrm{P}$, with three replicates per treatment. The experimental units were irrigated to that of reference crop evapotranspiration $\left(\mathrm{ET}_{0}\right)$ values according to Allen et al. (1998). The all other recommended agricultural practices for common beans were carried out as recommended by Abdelhamid et al. (2013). Treatments of KH were added at two equal doses; at 25 and 40 days after sowing (DAS).

\subsection{Measurements of Vegetative Growth Traits}

Fifty-day-old bean plants $(n=9)$ were removed and shoots were separated from plants, and the following vegetative growth attributes were recorded: Lengths of plants shoots were measured and number of leaves plant ${ }^{-1}$ was counted. Leaves area was measured using a leaf area meter (LI-COR 3100C, LI-COR, Inc., Lincoln, NE, USA). Fresh weights of shoots were assessed, and dry weights of shoots were recorded after placing them in an oven at $70^{\circ} \mathrm{C}$ until a constant weight.

\subsection{Yield Characteristics Assessments (Green Pods and Dry Seeds)}

At the marketable green pod stage of both experiments, green pods from randomly 5 rows (approximately 200 plants) from each treatment were collected, counted and weighed individually and per experimental plot $\left(10.5 \mathrm{~m}^{2}\right)$. At the end of both experiments, dry pods from the other 10 rows (approximately 400 plants) from each treatment were collected, seeds were extracted from pods, air-dried and weighed. 


\subsection{Determination of Leaf Pigments Contents and Chlorophyll Fluorescence}

Total chlorophylls and total carotenoids were extracted by homogenization of leaf sample ( $0.2 \mathrm{~g})$ in $80 \%$ acetone (50 ml). After filtration, the absorbance of the clear extract was measured at 663, 646 and $470 \mathrm{~nm}$ (Welburn and Lichtenthaler, 1984).

Chlorophyll fluorescence was measured on two different sunny days using a portable fluorometer (Handy PEA, Hansatech Instruments Ltd, Kings Lynn, UK). One leaf (the same age) was chosen per plant from three plants in each experimental plot of each treatment. Fluorescence measurements included: Maximum quantum yield of PS II Fv/Fm was calculated as; Fv/Fm = (Fm “Fo)/Fm (Maxwell and Johnson, 2000). Performance index of photosynthesis based on the equal absorption (PIABS) was calculated as reported by Clark et al. (2000).

\subsection{Determinations of $\mathrm{N}, \mathrm{P}, \mathrm{K}^{+}, \mathrm{Ca}^{2+}$, and $\mathrm{Na}^{+}$Contents}

Content of $\mathrm{N}(\%)$ was determined in powdery dried material of plants by Orange-G dye colorimetric method according to Hafez and Mikkelsen (1981).

The wet digestion of $0.1 \mathrm{~g}$ of fine dried material of plants was conducted using a sulphuric and perchloric acid mixture as mentioned by Piper (1947). The content of P (\%) was colorimetrically determined using chlorostannusmolybdophosphoric blue color method in sulphuric acid system as described by Jackson (1967). The content of $\mathrm{Ca}^{2+}(\%)$ was determined using a Perkin-Elmer Model 3300 Atomic Absorption Spectrophotometer (Chapman and Pratt, 1961). The contents of $\mathrm{K}^{+}(\%)$ and $\mathrm{Na}^{+}(\%)$ were determined using a Perkin-Elmer Flame photometer (Lachica et al., 1973).

\subsection{Calculations of $\mathrm{K}^{+} / \mathrm{Na}^{+}, \mathrm{Ca}^{2+} / \mathrm{Na}^{+}$and $\mathrm{K}^{+}+\mathrm{Ca}^{2+} / \mathrm{Na}^{+}$Ratios}

The ratios of $\mathrm{K}^{+} / \mathrm{Na}^{+}, \mathrm{Ca}^{2+} / \mathrm{Na}^{+}$and $\mathrm{K}^{+}+\mathrm{Ca}^{2+} / \mathrm{Na}^{+}$were calculated from the determined contents of $\mathrm{K}$, $\mathrm{Ca}$ and $\mathrm{Na}$.

\subsection{Statistical Analysis}

All values (in 9 samples per treatment; $n=9$ ) of the measured parameters for the common bean plants were subjected to statistical analysis following the standard procedures described by Gomez and Gomez (1984). Duncan's multiple range test was applied to assess the Least Significant Difference (LSD) of each treatment at a probability level of $95 \%(p \leq 0.05)$.

\section{Results}

\subsection{Effect of Soil Application With Potassium Humate (Kh) on Growth Traits of Salt-Stressed-Common Bean Plants}

Soil treatment with KH significantly increased the all tested growth characteristics (i.e., shoot length, number of leaves per plant, area of leaves per plant, and shoot fresh and dry weights) of salt-stressed common bean plants compared to the controls (without KH) (Table 2). The two tested KH levels showed no significant differences, except for the values of leaves area per plant of which $\mathrm{KH} 2$ significantly exceeded $\mathrm{KH} 1$ treatment and the control. Results of the two seasons showed the same trend. $\mathrm{KH}$ at $100 \mathrm{~kg}$ per feddan is found to be the preferred treatment.

Table 2: Effect of Soil Application With Phosphorus or Potassium Humate on Growth Traits of Common Bean (Phaseolus vulgaris L., cv. "Bronco") Plants Grown Under Soil Salinity Stress

\begin{tabular}{|c|c|c|c|c|c|c|c|c|c|c|}
\hline \multirow[b]{2}{*}{ Treatments } & \multicolumn{10}{|c|}{ Parameters } \\
\hline & $\begin{array}{c}\text { Shoot } \\
\text { Length } \\
(\mathrm{cm})\end{array}$ & $\begin{array}{c}\% \\
\text { of } \\
\text { Control }\end{array}$ & $\begin{array}{c}\text { No. of } \\
\text { Leaves } \\
\text { Plant }^{-1}\end{array}$ & $\begin{array}{c}\% \\
\text { of } \\
\text { Control }\end{array}$ & $\begin{array}{c}\text { Leaf } \\
\text { Area } \\
\text { Plant }^{-1} \\
\left(\mathbf{d m}^{2}\right)\end{array}$ & $\begin{array}{c}\% \\
\text { of } \\
\text { Control }\end{array}$ & $\begin{array}{c}\text { Shoot } \\
\text { Fresh } \\
\text { Weight } \\
\text { (g) }\end{array}$ & $\begin{array}{c}\% \\
\text { of } \\
\text { Control } \\
\text { dry }\end{array}$ & $\begin{array}{c}\text { Shoot } \\
\text { Dry } \\
\text { Weight } \\
\text { (g) }\end{array}$ & $\begin{array}{c}\% \\
\text { of } \\
\text { Control }\end{array}$ \\
\hline 2016 season & & & & & & & & & & \\
\hline Control & $25.4 b$ & - & $7.31 \mathrm{~b}$ & - & $9.51 \mathrm{c}$ & - & $25.0 \mathrm{~b}$ & - & $5.74 b$ & - \\
\hline KH 1 & $27.2 \mathrm{a}$ & +7.2 & $7.65 \mathrm{a}$ & +4.7 & $10.36 \mathrm{~b}$ & +8.9 & $29.3 \mathrm{a}$ & +17.2 & $6.88 \mathrm{a}$ & +19.9 \\
\hline $\mathrm{KH} 2$ & $28.2 \mathrm{a}$ & +11.0 & $7.85 \mathrm{a}$ & +7.4 & $11.19 \mathrm{a}$ & +17.7 & $31.4 \mathrm{a}$ & +25.6 & $7.43 \mathrm{a}$ & +29.4 \\
\hline
\end{tabular}


Table 2 (Cont.)

\begin{tabular}{|l|c|c|c|c|c|c|c|c|c|c|}
\hline & \multicolumn{9}{|c|}{ Parameters } \\
\cline { 2 - 11 } Treatments & $\begin{array}{c}\text { Shoot } \\
\text { Length } \\
(\mathbf{c m})\end{array}$ & $\begin{array}{c}\% \\
\text { of } \\
\text { Control }\end{array}$ & $\begin{array}{c}\text { No. of } \\
\text { Leaves } \\
\text { Plant }\end{array}$ & $\begin{array}{c}\% \\
\text { of } \\
\text { Control }\end{array}$ & $\begin{array}{c}\text { Leaf } \\
\text { Area } \\
\text { Plant } \\
\mathbf{d m}^{-1}\end{array}$ & $\begin{array}{c}\% \\
\text { of } \\
\text { Control }\end{array}$ & $\begin{array}{c}\text { Shoot } \\
\text { Fresh } \\
\text { Weight } \\
(\mathbf{g})\end{array}$ & $\begin{array}{c}\% \\
\text { of } \\
\text { Control } \\
\text { Dry }\end{array}$ & $\begin{array}{c}\text { Shoot } \\
\text { Dry } \\
\text { Weight } \\
(\mathbf{g})\end{array}$ & $\begin{array}{c}\% \\
\text { of } \\
\text { Control }\end{array}$ \\
\hline $\mathbf{2 0 1 7}$ Season & & & & & & & & & & \\
\hline Control & $26.1 \mathrm{~b}$ & - & $7.28 \mathrm{~b}$ & - & $9.58 \mathrm{c}$ & - & $25.8 \mathrm{~b}$ & - & $5.87 \mathrm{~b}$ & - \\
\hline KH1 & $27.8 \mathrm{a}$ & +6.5 & $7.59 \mathrm{a}$ & +4.3 & $10.56 \mathrm{~b}$ & +10.2 & $29.8 \mathrm{a}$ & +15.5 & $6.95 \mathrm{a}$ & +18.4 \\
\hline KH2 & $28.3 \mathrm{a}$ & +8.4 & $7.80 \mathrm{a}$ & +7.1 & $11.49 \mathrm{a}$ & +19.9 & $32.0 \mathrm{a}$ & +24.0 & $7.48 \mathrm{a}$ & +27.4 \\
\hline
\end{tabular}

Note: Mean values $(n=9)$ in each column for each year followed by a different lower-case letter are significantly different at $p \leq 0.05$ by Duncan's multiple range test. Control means plots without KH treatments, KH1 means $100 \mathrm{~kg}$ potassium humate per feddan, and KH2 means $200 \mathrm{~kg}$ potassium humate per feddan.

\subsection{Effect of Soil Application with KH on Yields of Salt-Stressed-Common Bean Plants}

Soil treatment with KH significantly increased the all tested green pods and dry seed yields characteristics [i.e., average pod weight, number of pods per plant, pods weight per plot $\left(10.5 \mathrm{~m}^{2}\right)$, dry seed weight per plot $\left(10.5 \mathrm{~m}^{2}\right)$ and 100 -seed weight] of salt-stressed common bean plants compared to the controls (without KH) (Table 3). The two tested KH levels showed no significant differences, except the parameter of pods weight per plant. Results of the two seasons conferred the same trend. $\mathrm{KH}$ at $100 \mathrm{~kg}$ per feddan is reported to be the preferred treatment.

Table 3: Effect of Soil Application With Phosphorus or Potassium Humate on Green Pod and Dry Seed Yields of Common Bean (Phaseolus vulgaris L., cv. "Bronco") Plants Grown Under Soil Salinity Stress

\begin{tabular}{|c|c|c|c|c|c|c|c|c|c|c|}
\hline \multirow[b]{2}{*}{ Treatments } & \multicolumn{10}{|c|}{ Parameters } \\
\hline & $\begin{array}{c}\text { Pod } \\
\text { Weight } \\
(\text { gm) }\end{array}$ & $\begin{array}{c}\% \\
\text { of } \\
\text { Control }\end{array}$ & $\begin{array}{c}\text { Pods } \\
\text { No. } \\
\text { Plant }^{-1}\end{array}$ & $\begin{array}{c}\% \\
\text { of } \\
\text { Control }\end{array}$ & $\begin{array}{c}\text { Pod } \\
\text { Weight } \\
\text { Plant }^{-1} \\
\text { (g) }\end{array}$ & $\begin{array}{c}\% \\
\text { of } \\
\text { Control }\end{array}$ & $\begin{array}{c}\text { Dry Seed } \\
\text { Weight } \\
\text { Plant }^{-1} \\
\text { (g) }\end{array}$ & $\begin{array}{c}\% \\
\text { of } \\
\text { Control } \\
\text { Dry }\end{array}$ & $\begin{array}{c}\text { 100- } \\
\text { Seed } \\
\text { Weight } \\
\text { (g) }\end{array}$ & $\begin{array}{c}\% \\
\text { of } \\
\text { Control }\end{array}$ \\
\hline \multicolumn{11}{|l|}{2016 season } \\
\hline Control & $2.20 \mathrm{~b}$ & - & $15.2 \mathrm{~b}$ & - & $31.5 \mathrm{c}$ & - & $10.6 \mathrm{~b}$ & - & $16.6 \mathrm{~b}$ & - \\
\hline KH 1 & $2.44 \mathrm{a}$ & +10.9 & $19.0 \mathrm{a}$ & +25.0 & $43.7 b$ & +38.7 & $12.0 \mathrm{a}$ & +13.2 & $18.4 \mathrm{a}$ & +10.8 \\
\hline $\mathrm{KH} 2$ & $2.54 \mathrm{a}$ & +15.5 & $20.6 \mathrm{a}$ & +35.5 & $49.4 \mathrm{a}$ & +56.8 & $12.3 \mathrm{a}$ & +16.0 & $19.3 \mathrm{a}$ & +16.3 \\
\hline \multicolumn{11}{|l|}{2017 Season } \\
\hline Control & $2.24 b$ & - & $15.5 \mathrm{~b}$ & - & $32.6 \mathrm{c}$ & - & $10.8 \mathrm{~b}$ & - & $17.2 \mathrm{~b}$ & - \\
\hline KH 1 & $2.50 \mathrm{a}$ & +11.6 & $19.5 \mathrm{a}$ & +25.8 & $46.0 \mathrm{~b}$ & +41.1 & $12.0 \mathrm{a}$ & +11.1 & $19.2 \mathrm{a}$ & +11.6 \\
\hline $\mathrm{KH} 2$ & $2.61 \mathrm{a}$ & +16.5 & $21.2 \mathrm{a}$ & +36.8 & $52.2 \mathrm{a}$ & +60.1 & $12.7 \mathrm{a}$ & +17.6 & $20.1 \mathrm{a}$ & +16.9 \\
\hline
\end{tabular}

Note: Mean values in each column for each year followed by a different lower-case letter are significantly different at $p \leq 0.05$ by Duncan's multiple range test. Control means plots without KH treatments, KH1 means $100 \mathrm{~kg}$ potassium humate per feddan, and $\mathrm{KH} 2$ means $200 \mathrm{~kg}$ potassium humate per feddan. 


\subsection{Effect of Soil Application with KH on the Contents of Leaf Photosynthetic Pigments and Chlorophyll Fluorescence Of Salt-Stressed-Common Bean Plants}

Soil application with KH significantly increased leaf photosynthetic pigments contents and chlorophyll fluorescence (i.e., total chlorophylls, total carotenoids, Fv/Fm and PI) of salt-stressed common bean plants compared to the controls (without KH) (Table 4). The two tested KH treatments showed no significant differences. Results of the two seasons represented the same trend. $\mathrm{KH}$ at $100 \mathrm{~kg}$ per feddan is represented to be the preferred treatment.

\begin{tabular}{|c|c|c|c|c|c|c|c|c|}
\hline \multirow[b]{2}{*}{ Treatments } & \multicolumn{8}{|c|}{ Parameters } \\
\hline & $\begin{array}{c}\text { Total } \\
\text { Chloro- } \\
\text { phylls }\end{array}$ & $\begin{array}{c}\% \\
\text { of } \\
\text { Control }\end{array}$ & $\begin{array}{c}\text { Total } \\
\text { Carote- } \\
\text { noids }\end{array}$ & $\begin{array}{c}\% \\
\text { of } \\
\text { Control }\end{array}$ & $\mathbf{F v} / \mathbf{F m}$ & $\begin{array}{c}\% \\
\text { of } \\
\text { Control }\end{array}$ & PI & $\begin{array}{c}\% \\
\text { of } \\
\text { Control }\end{array}$ \\
\hline \multicolumn{9}{|l|}{2016 Season } \\
\hline Control & $0.96 b$ & - & $0.32 b$ & - & $67.5 b$ & - & $60.6 b$ & - \\
\hline KH 1 & $1.59 \mathrm{a}$ & +65.6 & $0.38 \mathrm{a}$ & +18.8 & $79.6 \mathrm{a}$ & +17.9 & $72.0 \mathrm{a}$ & +18.8 \\
\hline KH2 & $1.67 \mathrm{a}$ & +74.0 & $0.40 \mathrm{a}$ & +25.0 & $81.8 \mathrm{a}$ & +21.2 & $74.3 \mathrm{a}$ & +22.6 \\
\hline \multicolumn{9}{|l|}{2017 Season } \\
\hline Control & $0.99 b$ & - & $0.34 \mathrm{~b}$ & - & $68.2 \mathrm{~b}$ & - & $61.0 \mathrm{~b}$ & - \\
\hline KH 1 & $1.64 \mathrm{a}$ & +65.7 & $0.43 \mathrm{a}$ & +26.5 & $80.9 \mathrm{a}$ & +18.6 & $72.5 \mathrm{a}$ & +18.9 \\
\hline KH2 & $1.71 \mathrm{a}$ & +72.7 & $0.45 \mathrm{a}$ & +32.4 & $83.7 \mathrm{a}$ & +22.7 & $74.2 \mathrm{a}$ & +21.6 \\
\hline
\end{tabular}

Note: Mean values $(\mathrm{n}=9)$ in each column for each year followed by a different lower-case letter are significantly different at $p \leq 0.05$ by Duncan's multiple range test. Control means plots without KH treatments, KH1 means $100 \mathrm{~kg}$ potassium humate per feddan, and $\mathrm{KH} 2$ means $200 \mathrm{~kg}$ potassium humate per feddan.

\subsection{Effect of Soil Application with KH on Leaf Contents of Nutrients and Sodium of Salt-Stressed-Common Bean Plants}

Soil application with KH significantly increased leaf contents of nitrogen $(\mathrm{N})$, phosphorus $(\mathrm{P})$, potassium $\left(\mathrm{K}^{+}\right)$, and calcium $\left(\mathrm{Ca}^{2+}\right)$, while significantly reduced leaf sodium $\left(\mathrm{Na}^{+}\right)$content of salt-stressed common bean plants compared to

Table 5: Effect of Soil Application with Phosphorus Or Potassium Humate on the Contents of Macro-Nutrients (N, P, $K^{+}$and $\mathrm{Ca}^{2+}$ ) and Sodium $\left(\mathrm{Na}^{+}\right)$of Common Bean (Phaseolus vulgaris L., cv. "Bronco") Plants Grown Under Soil Salinity Stress

\begin{tabular}{|c|c|c|c|c|c|c|c|c|c|c|}
\hline \multirow[b]{2}{*}{ Treatments } & \multicolumn{10}{|c|}{ Parameters } \\
\hline & $\begin{array}{c}\mathbf{N} \\
(\%)\end{array}$ & $\begin{array}{c}\% \\
\text { of } \\
\text { Control }\end{array}$ & $\begin{array}{c}P \\
(\%)\end{array}$ & $\begin{array}{c}\% \\
\text { of } \\
\text { Control }\end{array}$ & $\begin{array}{c}\mathbf{K}^{+} \\
(\%)\end{array}$ & $\begin{array}{c}\% \\
\text { of } \\
\text { Control }\end{array}$ & $\begin{array}{c}\mathrm{Ca}^{2+} \\
(\%)\end{array}$ & $\begin{array}{c}\% \\
\text { of } \\
\text { Control }\end{array}$ & $\begin{array}{l}\mathrm{Na}^{+} \\
(\%)\end{array}$ & $\begin{array}{c}\% \\
\text { of } \\
\text { Control }\end{array}$ \\
\hline \multicolumn{11}{|l|}{2016 Season } \\
\hline Control & $2.64 \mathrm{~b}$ & - & $0.28 \mathrm{c}$ & - & $2.55 \mathrm{~b}$ & - & $1.09 \mathrm{~b}$ & - & $0.64 \mathrm{a}$ & - \\
\hline KH 1 & $3.10 \mathrm{a}$ & +17.4 & $0.34 \mathrm{~b}$ & +21.4 & $2.93 \mathrm{a}$ & +14.9 & $1.21 \mathrm{a}$ & +11.0 & $0.46 \mathrm{~b}$ & 28.1 \\
\hline $\mathrm{KH} 2$ & $3.22 \mathrm{a}$ & +22.0 & $0.37 \mathrm{~b}$ & +32.1 & $3.16 \mathrm{a}$ & +23.9 & $1.27 \mathrm{a}$ & +16.5 & $0.40 \mathrm{c}$ & 37.5 \\
\hline
\end{tabular}




\begin{tabular}{|c|c|c|c|c|c|c|c|c|c|c|}
\hline \multicolumn{11}{|c|}{ Table 5 (Cont.) } \\
\hline \multirow[b]{2}{*}{ Treatments } & \multicolumn{10}{|c|}{ Parameters } \\
\hline & $\begin{array}{c}\mathrm{N} \\
(\%)\end{array}$ & $\begin{array}{c}\% \\
\text { of } \\
\text { Control }\end{array}$ & $\begin{array}{c}P \\
(\%)\end{array}$ & $\begin{array}{c}\% \\
\text { of } \\
\text { Control }\end{array}$ & $\begin{array}{c}\mathbf{K}^{+} \\
(\%)\end{array}$ & $\begin{array}{c}\% \\
\text { of } \\
\text { Control }\end{array}$ & $\begin{array}{c}\mathrm{Ca}^{2+} \\
(\%)\end{array}$ & $\begin{array}{c}\% \\
\text { of } \\
\text { Control }\end{array}$ & $\begin{array}{l}\mathrm{Na}^{+} \\
(\%)\end{array}$ & $\begin{array}{c}\% \\
\text { of } \\
\text { Control }\end{array}$ \\
\hline \multicolumn{11}{|l|}{2017 Season } \\
\hline Control & $2.71 \mathrm{~b}$ & - & $0.27 \mathrm{c}$ & - & $2.59 b$ & - & $1.03 \mathrm{~b}$ & - & $0.62 \mathrm{a}$ & - \\
\hline KH 1 & $3.13 \mathrm{a}$ & +15.5 & $0.35 b$ & +29.6 & $3.05 \mathrm{a}$ & +17.8 & $1.24 \mathrm{a}$ & +20.4 & $0.44 b$ & 29.0 \\
\hline $\mathrm{KH} 2$ & $3.21 \mathrm{a}$ & +18.5 & $0.38 b$ & +40.7 & $3.24 \mathrm{a}$ & +25.1 & $1.29 \mathrm{a}$ & +25.2 & $0.38 \mathrm{c}$ & 38.7 \\
\hline
\end{tabular}

the controls (without $\mathrm{KH}$ ) (Table 5). The two tested $\mathrm{KH}$ treatments showed no significant differences for N, P, $\mathrm{K}^{+}$, and $\mathrm{Ca}^{2+}$ contents. For $\mathrm{Na}^{+}$content, $\mathrm{KH} 2$ treatment significantly reduced $\mathrm{Na}^{+}$content compared to $\mathrm{KH} 1$ treatment, which in turn significantly reduced $\mathrm{Na}^{+}$content compared to the control. Results of the two seasons showed the same trend.

\subsection{Effect of Soil Application with $\mathrm{KH}$ on Antagonistic Relations of $\mathrm{K}^{+}$and $\mathrm{Ca}^{2+}$ with $\mathrm{Na}^{+}$of Salt-Stressed-Common Bean Plants}

Soil application with $\mathrm{KH}$ at the level of $200 \mathrm{~kg}$ per feddan $(\mathrm{KH} 2)$ significantly increased the ratios of $\mathrm{K}^{+} / \mathrm{Na}^{+}, \mathrm{Ca}^{2+} / \mathrm{Na}^{+}$, and $\mathrm{K}^{+}+\mathrm{Ca}^{2+} / \mathrm{Na}^{+}$in salt-stressed common bean plants compared to the level of $100 \mathrm{~kg}$ per feddan (KH1), which in turn significantly increased these ratios compared to the controls (without $\mathrm{KH}$ ) (Table 6). Results of the two seasons showed the same trend.

Table 6: Effect of Soil Application with Phosphorus or Potassium Humate on Nutrient Relations with Sodium (Na) Ions in Common Bean (Phaseolus vulgaris L., cv. "Bronco") Plants Grown Under Soil Salinity Stress

\begin{tabular}{|c|c|c|c|c|c|c|}
\hline \multirow[b]{2}{*}{ Treatments } & \multicolumn{6}{|c|}{ Parameters } \\
\hline & $\begin{array}{c}\mathbf{K}^{+} / \\
\mathrm{Na}^{+} \\
\text {Ratio }\end{array}$ & $\begin{array}{c}\% \\
\text { of } \\
\text { Control }\end{array}$ & $\begin{array}{c}\mathrm{Ca}^{2+} / \\
\mathrm{Na}^{+} \\
\text {Ratio }\end{array}$ & $\begin{array}{c}\% \\
\text { of } \\
\text { Control }\end{array}$ & $\begin{array}{c}\mathrm{K}^{+}+\mathrm{Ca}^{2+} / \\
\mathrm{Na}^{+} \\
\text {Ratio }\end{array}$ & $\begin{array}{c}\% \\
\text { of } \\
\text { Control }\end{array}$ \\
\hline \multicolumn{7}{|l|}{2016 Season } \\
\hline Control & $3.75 \mathrm{c}$ & - & $1.61 \mathrm{c}$ & - & $5.37 \mathrm{c}$ & - \\
\hline KH 1 & $5.99 \mathrm{~b}$ & +59.7 & $2.47 \mathrm{~b}$ & +53.4 & $8.46 b$ & +57.5 \\
\hline $\mathrm{KH} 2$ & $7.34 \mathrm{a}$ & +95.7 & $2.95 \mathrm{a}$ & +83.2 & $10.32 \mathrm{a}$ & +92.2 \\
\hline \multicolumn{7}{|l|}{2017 Season } \\
\hline Control & $3.93 \mathrm{c}$ & - & $1.57 \mathrm{c}$ & - & $5.52 \mathrm{c}$ & - \\
\hline KH 1 & $6.48 b$ & +64.9 & $2.64 b$ & +68.2 & $9.10 \mathrm{~b}$ & +64.9 \\
\hline KH2 & $8.11 \mathrm{a}$ & +106.4 & $3.22 \mathrm{a}$ & +105.1 & $11.35 \mathrm{a}$ & +105.6 \\
\hline
\end{tabular}

Note: Mean values $(n=9)$ in each column for each year followed by a different lower-case letter are significantly different at $p \leq 0.05$ by Duncan's multiple range test. Control means plots without KH treatments, KH1 means $100 \mathrm{~kg}$ potassium humate per feddan, and $\mathrm{KH} 2$ means $200 \mathrm{~kg}$ potassium humate per feddan. 


\section{Discussion}

In arid and semi-arid regions (dry environments), agricultural sector faces a massive problem due to salinity. Salinity occurred in growing media in such regions could be caused by one or more of the following reasons: (1) poor irrigation water which contains considerable amounts of salts, (2) accumulation of salts in the top layer of the soil due to overirrigation, (3) proximity to the sea, (4) capillarity rise of salts from underground water into the root zone due to excessive evaporation, (5) low rainfall, (6) high evaporation rate, and (7) poor water management (Rady et al., 2013; Semida et al., 2014; Rady et al., 2018; Seif El-Yazal, 2020; Rady et al., 2021). These soil salinization causes expose plants to osmotic stress. Salt stress adversely affects plant performance due to stimulating the overproduction of ROS through various organelles and enzymes (Semida et al., 2016; Seif El-Yazal et al., 2016). To avoid these effects, plants adopt several strategies such as ion homeostasis, osmotic adjustment and enhancing the antioxidative defense system (Xiong and Zhu, 2002).

Reduction in growth and yield characteristics (Tables 2 and 3) under soil salinity conditions may be attributed to a combination of osmotic and specific ion effects of $\mathrm{Cl}^{-}$and $\mathrm{Na}^{+}$, and the reduction in the uptake of some mineral nutrients such as $\mathrm{N}, \mathrm{P}, \mathrm{K}^{+}$and $\mathrm{Ca}^{2+}$ (Table 5), leading to declined ratios of $\mathrm{K}^{+} / \mathrm{Na}^{+}, \mathrm{Ca}^{2+} / \mathrm{Na}^{+}$and $\mathrm{K}^{+}+\mathrm{Ca}^{2+} / \mathrm{Na}^{+}$(Table 6). The depressive effect of salinity with $7.80-7.86 \mathrm{dS} \mathrm{m}^{-1}$, in this study, on growth and yields traits may also be attributed to a drop in total chlorophylls and total carotenoids contents, photosynthetic efficiency; Fv/Fm and PI (Table 4), and mineral nutrients uptake (Table 5).In this concern, salt stress affects plant physiology, both at the whole plant and cellular levels, through osmotic and ionic stress. Salinity generates a 'physiological drought' or osmotic stress by affecting the plant water relations (Munns, 2002; Seif El-Yazal et al., 2016; Seif El-Yazal et al., 2020). In addition, humic substances (i.e., potassium humate; $\mathrm{KH}$ ) improved the chemical properties of soil by increasing soil microorganisms that enhance nutrient uptake and reduce soil pH (Hemida et al., 2017; Osman and Rady, 2012), thus leading to increase in the absorption of nutrients $\mathrm{N}, \mathrm{P}, \mathrm{K}^{+}$, and $\mathrm{Ca}^{2+}$ and decrease in the absorption of $\mathrm{Na}^{+}$by $\mathrm{KH}$ application $\left(100 \mathrm{~kg} \mathrm{fedd}^{-1}\right)$ compared with the controls (Table 5). The positive effects of $\mathrm{KH}$ on plant growth could be referred to its acting as a source of plant growth regulators. In this concern, Nardi et al. (1999) have reported that humic acid had a gibberellins and auxin exhibiting higher amount of phenolic. Salinity potential decreases under KH treatment, so plant reduces its osmotic potential in order to absorb water and maintain turgor, evidence of the increase of relative water content, membrane stability index, DPPH, carotenoids, anthocyanin, soluble sugars, free proline, total flavonoids, total phenolics, $\mathrm{N}, \mathrm{P}$ and $\mathrm{K}^{+}$contents, and the decrease of electrolyte leakage, $\mathrm{Cl}$ and $\mathrm{Na}^{+}$(Taha and Osman, 2017). This led to enhancing morphological characters, reflecting positively in green pod and dry seed yields (Tables 2 and 3 ). In this respect, Kaya et al. (2005) have reported that humic acid application to green beans significantly increased number of seeds plant ${ }^{-1}$ and seed weight plant $^{-1}$.

Soil application of KH increased leaf contents of total chlorophylls, total carotenoids, photosynthesis efficiency; Fv/Fm and PI (Table 4), indicating that the humic acid reflected positive influence of water uptake or reduced water loss, more accumulation of compatible osmolytes such as soluble sugars, free proline, total flavonoids, total phenolics, carotenoids, total phenolics and anthocyanin leaf content and increase DPPH radical-scavenging activity which consequently causes increase in leaf water potential (Hemida et al., 2017; Taha and Osman, 2017). Hence, it could be concluded that the beneficial effect of humic acid on growth parameters of bean plants has been related to the efficiency of their water uptake and utilization also its role in accumulation of osmolytes. In addition, humic substances might upgrade the uptake of portion nutrients and diminish the uptake of $\mathrm{Cl}$ and $\mathrm{Na}^{+}$(Hemida et al., 2017; Taha and Osman, 2017).

The higher $\mathrm{N}, \mathrm{P}, \mathrm{K}^{+}$, and $\mathrm{Ca}^{2+}$ and lower $\mathrm{Na}^{+}$leaf contents were occurred with soil supply of $100 \mathrm{~kg} \mathrm{KH}$ feddan ${ }^{-1} \mathrm{KH}$ under $7.86 \mathrm{dS} \mathrm{m}^{-1}$ salinity conditions. The positive effect of humic acid on the uptake of nutrient elements might be due to their effect on leaf photosynthetic pigments contents and photosynthesis efficiency (Table 4), and on the accumulation of compatible osmolytes and antioxidants (Hemida et al., 2017; Taha and Osman, 2017). Also, humic acid similarly as a good fertilizer state creating more accessibility for the nutrients by reduction soil $\mathrm{pH}$ value as well as increasing the action of soil organisms (Hemida et al., 2017; Osman and Rady, 2012). Decrease in chlorophyll content in salinized plants may be due to increasing activity of chlorophyll-degrading enzyme chloroplast (Reddy and Vora, 1986). Plants overcome this adverse condition by increasing the proline accumulation in plants exposed to salt; water stress has been correlated in many species with their adaptation to osmotic stress (Taha and Osman, 2017). Complex atomic reactions including the accumulation of perfect solutes, the generation of stress proteins, and the expression of different sets of genes are parts of the plant, indicating also defense system against salinity stress (Hasegawa et al., 2000; Sairam and Tyagi, 2004). According to many researchers, humic substances might upgrade the uptake of portion nutrients; diminish the uptake for toxic components (Khaled and Fawy, 2011). 
The positive effect of humic acid on leaf content of $\mathrm{N}, \mathrm{P}, \mathrm{K}^{+}$and $\mathrm{Ca}^{2+}$ might be due to their effect on stability of membrance permeability (Zientara, 1983). Related to our results, El-Ghamry et al. (2009) and Taha and Osman (2017) have reported significant increases of N, P and $\mathrm{K}^{+}$leaf contents by utilizing of humic acid. Rady et al. (2016) have reported that soil application of humic acid led to significant reductions in the leaf contents of $\mathrm{Na}^{+}$in cotton plants.

\section{Conclusion}

The application of $\mathrm{KH}$ at a rate of $100 \mathrm{~kg}_{\text {fedd }}{ }^{-1}$ to soils enhance plant salinity stress defense responses, to act indirectly by improving general plant performances under stress, also, increasing the leaf photosynthetic pigments, $\mathrm{N}, \mathrm{P}, \mathrm{K}^{+}$and $\mathrm{Ca}^{2+}$ contents, and decreasing the content of $\mathrm{Na}^{+}$, leading to an increase in photosynthetic efficiency and, subsequently, to an increase in plant performances (growth and yields).

\section{References}

Abdelhamid, M.T., Rady, M.M., Osman, A.Sh. and Abdalla, M.S. (2013). Exogenous Application of Proline Alleviates Salt Induced Oxidative Stress in Phaseolus Vulgaris L. Plants. J. Hortic. Sci. Biotechnol., 88, 439-446.

Allen, R.G., Pereira, L.S., Raes, D. and Smith, M. (1998). Crop Evapotranspiration Guidelines for Computing Crop Water Requirements. Irrig. Drain., Paper 56, FAO, Rome, pp. 300.

Asada, K. (1999). The Water-water Cycle in Chloroplasts. Scavenging of Active Oxygens and Dissipation of Excess Photons. Annu. Rev. Plant Physiol. Plant Mol. Biol., 50, 601-639.

Bargaz, A., Nassar, R.M.A., Rady, M.M., Gaballah, M.S., Thompson, S.M., Brestic, M., Schmidhalter, U. and Abdelhamid, M.T. (2016). Improved Salinity Tolerance By Phosphorus Fertilizer in Two Phaseolus Vulgaris Recombinant Inbred Lines Contrasting in Their P-efficiency. J. Agron. Crop Sci., 202, 497-07.

Broughton, W.J., Hernander, G., Blair, B., Beebe, S., Gepts, P. and Vanderleyden, J. (2003). Beans (Phaseolus spp.) Model Food Legumes. Plant Soil, 252, 55-128.

Chapman, H.D. and Pratt, P.F. (1961). Methods of Analysis for Soil, Plants and Water. University of California, Division of Agricultural Science, Berkeley, CA, USA, pp. 56-63.

Clark, A.J., Landolt, W., Bucher, J.B. and Strasser, R.J. (2000). Beech (Fagus sylvatica) Response To Ozone Exposure Assessed With A Chlorophyll A Fluorescence Performance Index. Environ. Pollut., 109, $501-507$.

Dahnke, W.C. and Whitney, D.A. (1988). Measurement of soil salinity. In. Dahnke, W. C. (Ed.). Recommended Chemical Soil Test Procedures for the North Central Region. North Central Regional Publication 221. North Dakota Agric. Exp. St. Bull., 499. 32-34.

El-Ghamry, A.M., Abd El-Hai, K.M. and Ghoneem, K.M. (2009). Amino and Humic Acids Promote Growth, Yield and Disease Resistance of Faba Bean Cultivated in Clayey Soil. Aust. J. Basic Appli. Sci., 3. 731-739.

Gomez, K.A. and Gomez, A.A. (1984). Statistical Analysis Procedures for Agricultural Research. John Wiley and Sons, New York, NY, USA, pp. 25-30.

Hafez, A. R. and Mikkelsen, D.S. (1981). Colorimetric Determination of Nitrogen for Evaluating the Nutritional Status of Rice. Commun. Soil Sci. Plant Anal., 12, 61-69.

Hasegawa, P.M., Bressan, R.A., Zhu, J.K. and Bohnert, H.J. (2000). Plant Cellular And Molecular Responses to High Salinity. Annu. Rev. Plant Physiol. Plant Mol. Biol., 51, 463-499.

Hemida, Kh.A., Eloufey, A.Z.A., SeifEl-Yazal, M.A. and Rady, M.M. (2017). Integrated Effect of Potassium Humate and $\alpha$-tocopherol Applications on Soil Characteristics and Performance of Phaseolus vulgaris Plants Grown on a Saline Soil. Arch. Agron. Soil Sci., 63, 1556-1571.

Isaac, M.E., Harmand, J.M. and Drevon, J.J. (2011). Growth And Nitrogen Acquisition Strategies of Acacia Senegal Seedlings Under Exponential Phosphorus Additions. J. Plant Physiol., 168, 776-781.

Jackson, M.L. (1967). Soil Chemical Analysis. Prentice Hall of India Pvt. Ltd, New Delhi, India, pp. 144-197, 326-338.

Kaya, M., Atak, M., Khawar, K.M., Cemalettin, Y.C. and Özcan, S. (2005). Effect Of Pre-sowing Seed Treatment With Zinc and Foliar Spray of Humic Acids on Yield of Common Bean (Phaseolus vulgaris, L.). Intl J. Agric. Biol., 7, 875-878.

Khaled, H. and Fawy, H.A. (2011). Effect of Different Levels of Humic Acids on the Nutrient Content, Plant Growth, and Soil Properties Under Conditions of Salinity. Soil Water Res., 6, 21-29. 
Khan, M.I., R., Mughal, A., Iqbal, N. and Khan, N.A. (2013). Potentiality of Sulphur Containing Compounds in Salt Stress Tolerance. In. Parvaiz, A., Azooz, M. M., Prasad, M. N. V. (Eds.). Ecophysiology and Responses of Plants Under Salt Stress. Chapter 17, p. 443-472, Springer.

Klute, A. (1986). Methods of Soil Analysis. Part 1. Physical and Mineralogical Methods. 2nd Ed. Wisconsin, USA. American Society of Agronomy Madison.

Lachica, M., Aguilar, A. and Yanez, J. (1973). Analisis Foliar. Métodos Utilizados enla EstaciLn Experimental del Zaidin, 32. Anales de Edafologia y Agrobiologia, pp. 1033-1047.

Maas, E.V. and Hoffman, G.J. (1977). Crop Salt Tolerance-Current Assessment. Journal of the Irrigation and Drainage Division-PUBDB, 103(2), 115-134.

Maxwell, K. and Johnson, G.N. (2000). Chlorophyll Fluorescence-A Practical Guide. J. Exp. Bot., 51, 659-668.

Mishra, M., Mishra, P.K., Kumar, U. and Prakash, V. (2009). NaCl Phytotoxicity Induces Oxidative Stress and Response of Antioxidant System in Cicer arietinum L. cv. Abrodbi. Bot. Res. Intl., 2, 74-82.

Munns, R. (2002). Comparative Physiology of Salt and Water Stress. Plant Cell Environ., 25, 239-250.

Munns, R. and Tester, M. (2008). Mechanisms of Salinity Tolerance. Annu. Rev. Plant Biol., 59, 651-681.

Nardi, M.R., Diego, P., Fabiano, R. and Muscolo, A. (1999). Biological Activity of Humic Substances Extracted from Soils Under Different Vegetation Cover. Commun. Soil Sci. Plant Anal., 30, 621-634.

Osman, A.Sh. and Rady, M.M. (2012). Ameliorative Effects of Sulphur and Humic Acid on the Growth, Antioxidant Levels and Yields of Pea (Pisum sativum L.) Plants Grown in Reclaimed Saline Soil. J. Hortic. Sci. Biotechnol., 87(6), 626-632.

Page, A.I., Miller, R.H. and Keeney, D.R. (1982). Methods of Soil Analysis. Part 2. Chemical and Microbiological Properties. $2^{\text {nd }}$ Ed. American Society of Agronomy, Madison, Wisconsin, USA.

Piper, C.S. (1947). Soil and Plant Analysis. Inter. Sci. Inc. Nc. USA.

Rady, M.M., Abd El-Mageed, T.A., Abdurrahman, H.A. and Mahdi, A.H. (2016). Humic Acid Application Improves Field Performance of Cotton (Gossypium barbadense L.) Under Saline Conditions. J. Anim. Plant Sci., 26(2), 487-493.

Rady, M.M., Varma, B.C. and Howladar, S.M. (2013). Common Bean (Phaseolus vulgaris L.) Seedlings Overcome NaCl Stress as a Result of Presoaking in Moringa oleifera Leaf Extract. Sci. Hortic., 162. 63-70.

Rady, M.M., El-Shewy, A.A., Seif El-Yazal, M.A. and Abdelaal Kariman E.S. (2018). Response of Salt-Stressed Common Bean Plant Performances to Foliar Application of Phosphorus (MAP). International Letters of Natural Sciences, 72, 7-20.

Rady, M.M., Seif El-Yazal, M.A., Aly Taie, H.A. and Ahmed, S.M.(2021). Physiological and Biochemical Responses of Wheat (Triticum Aestivum L.) Plants To Polyamines Under Lead Stress. Innovare Journal of Agri. Sci., 9(1), 1-10.

Reddy, M.P. and Vora, A.B. (1986). Changes in Pigment Composition, Hill Reaction Activity and Saccharides Metabolism in Bajra (Pennise tumtyphoides S\&H) Leaves NaCl Salinity. Photosynthica, 20, 50-55.

Sairam, R.K. and Tyagi, A. (2004). Physiology and Molecular Biology of Salinity Stress Tolerance in Plants. Curr. Sci., 86. 407-421.

Seif El-Yazal, M.A., Eissa, H.S., Ahmed, S.M., Howladar, S.M., Zaki, S.S. and Rady, M.M. (2016). The mtlD Geneoverexpressed Transgenic Wheat Tolerates Salt Stress Through Accumulation of Mannitol and Sugars. Plant, 4(6), 78-90.

Seif El-Yazal, M.A. (2020). Impact of Some Organic Manure With Chemical Fertilizers on Growth and Yield of Broad Bean (Vicia Faba L.) Grown in Newly Cultivated Land. Sustainable Food Production, 9, 23-36.

Seif El-Yazal, M.A., El-Shewy, A.A., Abdelaal, K.E.S. and Rady, M.A. (2020).Impacts of Phosphorus as Soil Application on Growth, Yield and Some Chemical Constitutes of Common Bean Plants Grown Under Saline Soil Conditions. Sustainable Food Production, 7, 24-36.

Semida, W.M., Abd El-Mageed, T.A., Howladar, S.M. and Rady, M.M. (2016). Foliar-Applied $\alpha$-Tocopherol Enhances Salt-tolerance in Onion Plants By Improving Antioxidant Defence System. Aust. J. Crop Sci., 10(7), 1835-2707. 
Semida, W.M., Abd El-Mageed, T.A., Howladar, S.M., Mohamed, G.F. and Rady, M.M. (2015). Response of Solanum melongena L. Seedlings Grown Under Saline Calcareous Soil Conditions to a New Organo-Mineral Fertilizer. J. Anim. Plant Sci., 25(2), 485-493.

Semida, W.M., Taha, R.S., Abdelhamid, M.T. and Rady, M.M. (2014). Foliar-Applied $\alpha$-Tocopherol Enhances Salttolerance In Vicia Faba L. Plants Grown Under Saline Conditions. S. Afr. J. Bot., 95, 24-31.

Taha, S.S. and Osman, A.Sh. (2017). Influence of Potassium Humate on Biochemical and Agronomic Attributes of Bean Plants Grown on Saline Soil. J. Hortic. Sci. Biotechnol., DOI. 10.1080/14620316.2017.1416960

Wang, X.W., Vinocur, B. and Altman, A. (2003). Plant Responses to Drought, Salinity and Extreme Temperatures. Towards Genetic Engineering for Stress Tolerance. Planta, 218, 1-14.

Welburn, A.R. and Lichtenthaler, H. (1984). Formulae and Program to Determine Total Carotenoids and Chlorophylls A and B Leaf Extracts in Different Solvents. In. Advances in Photosynthesis Research (Sybesma, C., Ed.), (2), 9-12.

Xiong, L. and Zhu, J.K. (2002). Molecular and Genetic Aspects of Plant Responses to Osmotic Stress. Plant Cell Environ., 25, 131-139.

Yasar, F., Kusvuran, S. and Ellialtioçlu, S. (2006). Determination of Anti-Oxidant Activities in Some Melon (Cucumis Melo L.) Varieties and Cultivars Under Salt Stress. J. Hortic. Sci. Biotechnol., 81, 627-630.

Yildirim, B., Yaser, F., Ozpay, T., TurkOzu, D., Terzio lu, O. and Tamkoc, A. (2008). Variations in Response to Salt Stress Among Field Pea Genotypes (Pisum sativum sp. arvense L.). J. Anim. Vet. Adv., 7, 907-910.

Zientara, M. (1983). Effect of Sodium Humate on Membrane Potential in Internodal Cells of Starry Stonewort (Nitellopsis obtuse). Acta Soc. Bot. Pol., 52, 271-277.

Cite this article as: Mohamed A. Seif El-Yazal, Ahmed A. El-Shewy, Kariman E.S. Abdelaal and Mostafa M. Rady (2021). Improved Salinity Tolerance by Potassium Humate Fertilizer in Common Bean (Phaseolus vulgaris L., Cv. "Bronco") Plants. International Journal of Agricultural Sciences and Technology. 1(4), 47-57. doi: 10.51483/ IJAGST.1.4.2021.47-57. 